\title{
Kaldu Ayam Instan dengan Substitusi Tepung Hati Ayam sebagai Alternatif Bumbu untuk Mencegah Anemia
}

\section{Instant Chicken Broth with Chicken Liver Powder as an Alternative Seasoning to Prevent Anemia}

\author{
Annisa Rizky Malichati* ${ }^{1}$, Annis Catur Adi $^{1}$
}

\begin{abstract}
ABSTRAK
Latar Belakang: Kaldu ayam instan dengan substitusi tepung hati ayam berpotensi untuk menjadi penyedap non-MSG yang memiliki manfaat kesehatan terutama sebagai alternatif pencegahan anemia. Inovasi pengolahan hati ayam pada produk sekaligus dapat meningkatkan nilai guna jerohan sebagai by-product.

Tujuan: Penelitian ini bertujuan untuk mengetahui mutu organoleptik dan kandungan protein, lemak, kadar air, dan zat besi pada produk kaldu ayam instan dengan substitusi tepung hati ayam.

Metode: Penelitian ini menggunakan desain eksperimental murni dengan Rancangan Acak Lengkap (RAL) dengan 4 (empat) taraf perlakuan. Tepung hati ayam disubstitusikan pada $300 \mathrm{~g}$ bahan pengisi tepung terigu dengan persentase $0 \%, 10 \%, 30 \%$, dan $40 \%$, kemudian dilakukan uji organoleptik yang dianalisis secara deskriptif dan inferensial menggunakan uji Kruskal Wallis dengan uji lanjutan Mann Whitney. Analisis kandungan gizi dilakukan hanya pada formula terpilih dari hasil analisis deskriptif uji organoleptik.

Hasil: Hasil uji organoleptik menunjukkan produk dengan mutu organoleptik tertinggi adalah F1 dengan substitusi tepung hati ayam sebesar $10 \%$. Substitusi tepung hati ayam memberikan pengaruh secara signifikan terhadap tekstur $(p=0,000)$ dan rasa $(p=0,007)$ dari produk kaldu ayam instan. Kandungan gizi kaldu ayam instan F1 sudah memenuhi standar kaldu bubuk dengan 10,24\% protein, 2,87\% lemak, 3,67\% air, dan 20,42 ppm zat besi dalam $100 \mathrm{~g}$ sajian.

Kesimpulan: Dapat disimpulkan kaldu ayam instan dengan substitusi $10 \%$ tepung hati ayam memiliki mutu organoleptik yang baik dan berpotensi menjadi alternatif bumbu non-MSG tambahan untuk mencegah anemia, karena memiliki kandungan protein dan zat besi yang lebih tinggi dibandingkan kaldu ayam instan komersial.
\end{abstract}

Kata Kunci: anemia, bumbu, kaldu ayam instan, tepung hati ayam. 


\section{ABSTRACT}

Background: Instant chicken broth with chicken liver powder substitution had a potential to become a non-MSG alternative seasoning with health value, especially to prevent anemia. Innovation of processing chicken liver into the product could increase its value as a by-product.

Objective: This research was aimed to determine product's organoleptic quality and nutritional values (protein, fat, water and iron).

Methods: This research was true experimental design with Complete Randomized Design (CRD) with four levels. Level of chicken liver powder substitution to $300 \mathrm{~g}$ flours as broth's filling were 0\%, 10\%, 30\% and 40\%. Organoleptic test to determine product's acceptance was statistically analyzed by descriptive and inferential analysis, with Kruskal Wallis and Mann Whitney test. Analysis of nutritional values only for the chosen formula from organoleptic test's result.

Results: The chosen formula which had the highest organoleptic quality score was F1 with $10 \%$ chickenliver powder substitution. The texture $(p=0.000)$ and taste $(p=0.007)$ of instant chicken broth was significantly affected by chicken liver powder substitution. Nutritional value of product had met the requirement of instant broth standart with $10.24 \%$ protein, $2.87 \%$ fat, 3.67\% water, and $20.42 \mathrm{ppm}$ iron in $100 \mathrm{~g}$ serving.

Conclusion: It could be concluded that instant chicken broth with $10 \%$ chicken liver powder substitution had a good organoleptic quality and had a potential to be non-MSG alternative seasoning to prevent anemia. The product contained higher protein and iron compared to commercial instant chicken broth.

Keywords: anemia, chicken liver powder, instant chicken broth, seasoning.

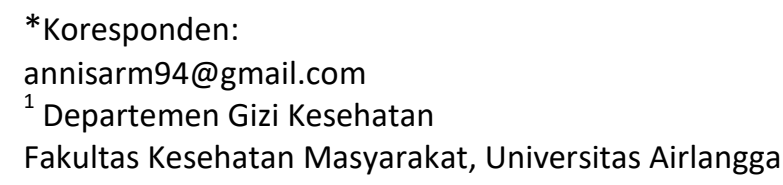

\section{PENDAHULUAN}

Masalah gizi mikro pada Wanita Usia Subur (WUS) yang masih memiliki prevalensi yang tinggi di Indonesia adalah anemia defisiensi besi ${ }^{1}$. Pemerintah sudah menerapkan berbagai program untuk mengatasinya seperti suplementasi Tablet Tambah Darah (TTD) dan fortifikasi pada tepung terigu, namun masih belum bisa mengatasi masalah terebut. Rekomendasi kebutuhan zat besi harian pada WUS menurut AKG adalah $26 \mathrm{mg} /$ hari dan angka tersebut cukup tinggi untuk dipenuhi apabila tidak menerapkan pola konsumsi yang beragam². Produk dengan bentuk instan saat ini merupakan produk yang populer digunakan di masyarakat, sehingga salah satu bentuknya seperti penyedap rasa atau kaldu instan berpotensi menjadi alternatif media penanganan masalah gizi mikro, termasuk

sebagai media fortifikasi untuk mengatasi anemia defisiensi zat besi. Pemanfaatan bumbu dapur sebagai fortifikan pernah diteliti pada wanita di Afrika Selatan dan penggunaan bumbu dapur yang telah diperkaya dengan zat besi tersebut dapat meningkatkan konsentrasi hemoglobin pada subyek yang diteliti ${ }^{3}$.

Kaldu merupakan hasil dari ekstrak bahan makanan tertentu seperti daging ayam, daging sapi, seafood, dan sayuran yang ditujukan untuk meningkatkan rasa gurih pada masakan. Kaldu instan komersial yang dijual bebas di pasaran sebagian besar diberi penambahan zat Mono Sodium Glutamat 
(MSG) sebagai penguat rasa. Penggunaan penguat rasa MSG hingga saat ini masih menjadi perdebatan di masyarakat. Permasalahan tersebut bermula dari dimuatnya surat yang ditulis oleh Dr. Robert Ho Man Kwok di New England Journal of Medicine (NEJM) tahun 1968 mengenai Chinese Restaurant Syndrome (CRS), dan kontroversi keamanan penggunaan MSG masih terus berlanjut hingga sekarang meskipun Food and Drug Administration (FDA) mengeluarkan pernyataan bahwa penggunaan MSG dalam batas yang wajar tidak membahayakan kesehatan manusia ${ }^{4}$.

Kaldu dapat dimodifikasi dengan bahan makanan lain dalam pembuatannya untuk meningkatkan manfaatnya bagi kesehatan, contohnya dengan menambahkan hati ayam yang mengandung tinggi zat besi $(7,16 \mathrm{mg} / 100$ g), magnesium, vitamin C, vitamin B12, dan asam folat ke dalam resep kaldu sebagai pencegahan anemia ${ }^{5}$. Hati ayam adalah salah satu organ yang termasuk limbah atau byproduct namun memiliki keunggulan dibanding hati yang bersumber dari ternak lainnya, karena harganya lebih murah dan lebih mudah ditemukan di pasaran. Namun pengolahan hati ayam sendiri masih kurang beragam dan kurang maksimal dalam pemanfaatan potensialnya.

Berdasarkan latar belakang tersebut maka pembuatan produk ini dapat meningkatkan potensi pemanfaatan hati ayam dan menurunkan limbah, serta menyediakan produk penyedap rasa alternatif bagi masyarakat yang mengindari penggunaan MSG namun membutuhkan produk instan serupa yang sekaligus memilliki manfaat kesehatan. Tujuan substitusi hati ayam dalam penelitian ini adalah untuk mengetahui mutu organoleptik dan kandungan protein, lemak, kadar air, dan zat besi yang terkandung dalam kaldu ayam instan.

\section{METODE}

Pengembangan produk kaldu ayam instan pada penelitian ini menggunakan desain eksperimental murni dengan rancangan percobaan menggunakan Rancangan Acak Lengkap (RAL). Prinsip modifikasi formula dalam pembuatan kaldu ayam instan ini adalah dengan memodifikasi bahan pengisi kaldu, yaitu tepung terigu dan tepung hati ayam, sebanyak $15 \%$ dari berat total dari resep yang digunakan. Terdapat 4 (empat) taraf perlakuan dalam modifikasi, yaitu $0 \%$ substitusi tepung hati ayam dan $100 \%$ tepung terigu (F0), $10 \%$ substitusi tepung hati ayam dan $90 \%$ tepung terigu (F1), $30 \%$ tepung hati ayam dan $70 \%$ tepung terigu (F2), dan yang terakhir $40 \%$ tepung hati ayam dan $60 \%$ tepung terigu (F3). Produk formulasi dibuat di Laboratorium Gizi Fakultas Kesehatan Masyarakat Universitas Airlangga dan dilaksanakan pada bulan Juni-Agustus 2017.

\section{Alat dan Bahan}

Bahan-bahan dalam pembuatan produk kaldu ayam instan pada penelitian ini secara dasar terdiri dari bahan kaldu ayam dan bahan tepung hati ayam. Bahan kaldu yang dibutuhkan adalah air, tulang ayam, tomat, bawang merah, bawang putih, garam, gula, merica, dan tepung terigu sebagai bahan pengisi kaldu. Bahan pembuatan tepung hati ayam adalah hati ayam, bawang bombay, bawang putih, dan jeruk nipis. Peralatan yang digunakan dalam penelitian adalah oven, panci presto, saringan, teflon, blender, dan ayakan. Tahap pembuatan dimulai dari pembuatan tepung hati ayam terlebih dahulu, kemudian selanjutnya pembuatan kaldu ayam instan.

\section{Pembuatan Tepung Hati Ayam}

Tepung hati ayam dibuat dengan cara pencucian hati ayam di bawah air mengalir, kemudian direndam dengan perasan jeruk nipis sebanyak $1 \%$ berat basah dari hati ayam selama 2 menit untuk mengurangi cemaran bakteri campylobacter ${ }^{6}$. Setelah itu, hati ayam ditiriskan dan ditumis dengan bawang bombay dan bawang putih yang sudah dihaluskan hingga matang selama \pm 3 menit. Selanjutnya hati ayam yang sudah matang dilumatkan dan dikeringkan dengan pengeringan oven suhu $60^{\circ} \mathrm{C}$ selama $4 \mathrm{jam}^{7}$. Hati ayam yang sudah kering dihancurkan dengan blender dan diayak menggunakan ayakan ukuran 70 mesh 
untuk memperoleh tekstur tepung hati ayam yang halus.

\section{Pembuatan Kaldu Instan}

Pembuatan kaldu ayam menggunakan modifikasi resep dari UKM "Rumah Herbal Toga Citra". Tahap pertama yaitu persiapan dan pencucian bahan baku dibawah air mengalir. Dalam panci presto ukuran besar, disiapkan air untuk perebusan dengan perbandingan 5 kali dari berat tulang ayam. Semua bahan seperti tulang ayam, tomat, bawang merah, bawang putih, dan bumbubumbu (garam, gula, merica) direbus dengan suhu $\pm 90^{\circ} \mathrm{C}$ selama 4 jam. Setelah itu isi kaldu disaring untuk mendapatkan kaldu cair (filtrat) yang berwarna putih kekuningan. Filtrat kaldu diberi tambahan bahan pengisi yaitu tepung terigu atau tepung hati sebelum dikeringkan. Setelah diaduk rata, campuran kaldu dan tepung yang berbentuk pasta dikeringkan menggunakan teflon anti lengket dengan cara dihamparkan secara tipis $\pm 0,25 \mathrm{~mm}$ dan dikeringkan selama \pm 2 menit. Lembaran kaldu yang sudah mengering dihancurkan dengan blender dan diayak menggunakan ayakan ukuran 70 mesh untuk memperoleh tekstur bubuk yang halus.

\section{Pengujian Organoleptik}

Pengujian mutu organoleptik meliputi aspek warna, aroma, tekstur, dan rasa yang dinilai dengan skala hedonik 1 hingga 4 oleh 30 panelis tidak terlatih, yaitu mahasiswi Universitas Airlangga dengan rentang usia 1029 tahun. Skala hedonik tersebut merepresentasikan tingkat kesukaan panelis mulai dari sangat tidak suka, tidak suka, suka, dan sangat suka. Semakin tinggi skor yang diberikan maka semakin baik skor dari mutu organoleptik tersebut. Data hasil penilaian mutu organoleptik dianalisis secara deskriptif dan inferensial menggunakan uji Kruskall Wallis dengan tingkat kepercayaan 95\%, jika analisis menghasilkan pengaruh yang nyata maka dilanjutkan dengan analisis Mann Whitney dengan tingkat kepercayaan yang sama.

\section{Analisis Kandungan Gizi}

Analisis kandungan gizi dilakukan di Laboratorium Fakultas Kesehatan Masyarakat Universitas Airlangga. Analisa zat gizi meliputi zat besi dengan metode Atomic Absorbtion Spectrophotometry (AAS), protein dengan metode Kjeldahl, lemak dengan metode Soxhlet, dan kadar air menggunakan metode pengeringan oven. Analisis zat gizi hanya dilakukan pada formula terbaik berdasarkan hasil akumulasi nilai mutu organoleptik oleh panelis.

Penelitian pengembangan produk kaldu ayam instan ini telah lulus uji komite etik dan mendapatkan sertifikat laik etik no: 354-KEPK Fakultas Kesehatan Masyarakat Universitas Airlangga.

\section{HASIL DAN PEMBAHASAN}

Kaldu ayam instan dengan substitusi hati ayam dalam penelitian ini ditujukan sebagai inovasi Bahan Tambahan Pangan (BTP) dengan sasaran pencegahan anemia pada Wanita Usia Subur (WUS). Hasil dari uji hedonik pada mutu organoleptik digunakan untuk menentukan formula terbaik dan mengetahui pengaruh substitusi tepung hati ayam terhadap indikator warna, aroma, tekstur, dan rasa.

\section{Nilai Organoleptik Warna}

Warna dalam mutu organoleptik dapat dinilai dengan indera pengelihatan mata untuk memberikan kesan ketertarikan visual awal pada suatu produk $^{8}$. Hasil skor mutu organoleptik warna oleh panelis dapat dilihat pada Tabel 1. Mean rank penilaian warna menunjukkan skor warna tertinggi diperoleh F2 yang memiliki warna coklat agak tua dengan rata-rata 3,10 , sementara itu formula dengan skor terendah didapatkan pada FO yang memiliki warna yang lebih cerah dibandingkan formula lainnya. Prosentase substitusi tepung hati ayam yang semakin tinggi menyebabkan warna kaldu ayam instan berubah menjadi lebih gelap. Perubahan warna menjadi kecoklatan dipengaruhi oleh terbentuknya pigmen coklat pada reaksi maillard yang terjadi saat proses pemanggangan hati ayam dan pengeringan filtrat kaldu menjadi bubuk instan. Reaksi 
maillard terbentuk karena terdapat reaksi kimia antara asam amino bebas dari protein hati ayam dengan gugus gula pereduksi sehingga pada prosesnya terbentuk pigmen coklat bernama melanoidin yang menyebabkan produk kaldu ayam instan menjadi kecoklatan ${ }^{9}$.

Tabel 1. Mutu Organoleptik Warna Kaldu Ayam Instan

\begin{tabular}{ccccc}
\hline Mutu Organoleptik & Formula & Mean Rank & Karakteristik & p-value \\
\hline \multirow{3}{*}{ Warna } & F0 $(0 \%)$ & 2,97 & putih kecoklatan & \\
\cline { 2 - 4 } & F1 (10\%) & 3,03 & \multirow{2}{*}{0,967} \\
\cline { 2 - 4 } & F2 $(30 \%)$ & 3,10 & coklat & \\
\cline { 2 - 4 } & F3 $(40 \%)$ & 3,03 & coklat agak tua & \\
\hline
\end{tabular}

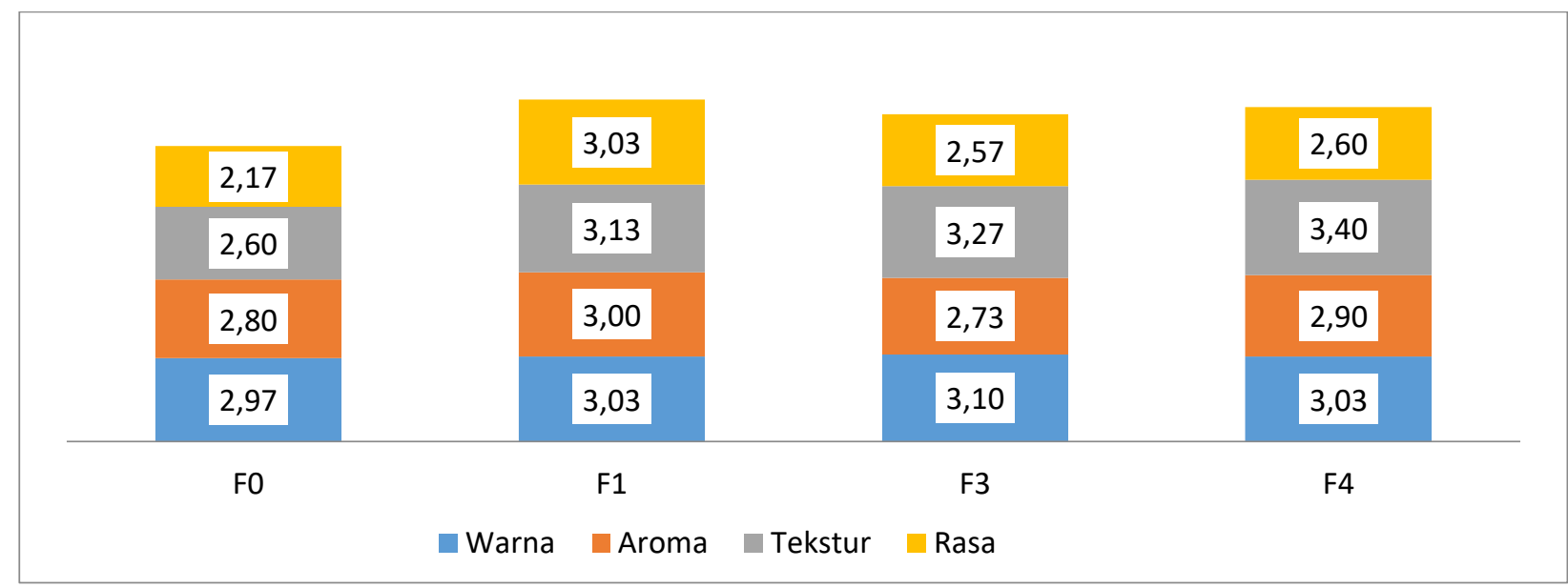

Gambar 1. Akumulasi hasil uji hedonik indikator mutu organoleptik produk kaldu ayam instan

Tabel 2. Mutu Organoleptik Aroma Kaldu Ayam Instan

\begin{tabular}{ccccc}
\hline Mutu Organoleptik & Formula & Mean Rank & Karakteristik & p-value \\
\hline & F0 (0\%) & 2,80 & gurih & \\
\cline { 2 - 4 } Aroma & F1 (10\%) & 3,00 & $\begin{array}{c}\text { gurih dan khas } \\
\text { ayam panggang }\end{array}$ & \\
\cline { 2 - 4 } & F2 (30\%) & 2,73 & $\begin{array}{c}\text { gurih dan khas } \\
\text { ayam panggang }\end{array}$ & 0,629 \\
\cline { 2 - 4 } & F3 (40\%) & 2,90 & $\begin{array}{c}\text { gurih, khas ayam } \\
\text { panggang } \\
\text { hati amis am } \\
\text { hati ayam }\end{array}$ & \\
\hline
\end{tabular}

Keterangan: tanda ' + ' menunjukkan meningkatnya intensitas aroma

Tabel 3. Mutu Organoleptik Tekstur Kaldu Ayam Instan

\begin{tabular}{|c|c|c|c|c|}
\hline Mutu Organoleptik & Formula & Mean Rank & Karakteristik & $p$-value \\
\hline \multirow{4}{*}{ Tekstur } & F0 (0\%) & $2,60^{\mathrm{a}}$ & bubuk halus & \multirow{4}{*}{0,000} \\
\hline & F1 (10\%) & $3,13^{b}$ & $\begin{array}{l}\text { bubuk halus dan } \\
\text { lembab }\end{array}$ & \\
\hline & F2 (30\%) & $3,27^{b}$ & $\begin{array}{l}\text { bubuk halus dan } \\
\text { lembab }\end{array}$ & \\
\hline & F3 (40\%) & $3,40^{b}$ & $\begin{array}{l}\text { bubuk halus dan } \\
\text { lembab }\end{array}$ & \\
\hline
\end{tabular}

Keterangan: notasi superskrip yang berbeda pada kolom mean rank menunjukkan adanya perbedaan signifikan $(p<0,05)$. Tanda ' + ' menunjukkan meningkatnya intensitas tekstur. 
Tabel 4. Mutu Organoleptik Rasa Kaldu Ayam Instan

\begin{tabular}{ccccc}
\hline Mutu Organoleptik & Formula & Mean Rank & Karakteristik & p-value \\
\hline \multirow{3}{*}{ Rasa } & F0 $(0 \%)$ & $2,17^{\mathrm{a}}$ & gurih & \\
\cline { 2 - 4 } & $\mathrm{F} 1(10 \%)$ & $3,03^{\mathrm{b}}$ & gurih dan asin & \multirow{2}{*}{0,007} \\
\cline { 2 - 4 } & $\mathrm{F} 2(30 \%)$ & $2,57^{\mathrm{ab}}$ & gurih dan $\operatorname{asin}^{+}$ & \\
\cline { 2 - 4 } & $\mathrm{F} 3(40 \%)$ & $2,60^{\mathrm{ab}}$ & gurih dan $\operatorname{asin}^{++}$ & \\
\hline
\end{tabular}

Keterangan: notasi superskrip yang berbeda pada kolom mean rank menunjukkan adanya perbedaan signifikan $(p<0,05)$. Tanda ' + ' menunjukkan meningkatnya intensitas rasa.

Hasil dari mean rank yang lebih tinggi pada formula modifikasi menunjukkan bahwa panelis memiliki preferensi kaldu yang memiliki warna coklat agak tua dibandingkan warna yang lebih terang. Warna coklat pada kaldu merupakan warna yang lebih mendekati warna asli dari bahan baku filtrat kaldu ayam dan hati ayam sehingga memberikan kesan identitas dan intensitas rasa suatu produk menjadi lebih alami ${ }^{10}$. Namun secara analisis statistik menggunakan Kruskall Wallis menunjukkan substitusi tepung hati ayam pada kaldu ayam instan tidak memberikan pengaruh secara nyata ( $p$-value $=0,967)$ pada mutu organoleptik warna.

\section{Nilai Organoleptik Aroma}

Aroma pada mutu organoleptik dinilai menggunakan indera penciuman hidung dengan media perantara reseptor olfaktori yang bekerja menangkap zat di udara yang melewati rongga hidung ${ }^{8}$. Hasil skor mutu organoleptik aroma dapat dilihat pada Tabel 2. Mean rank penilaian aroma menunjukkan F1 mendapatkan skor tertinggi, yaitu 3,00 dengan karakteristik aroma yang gurih dan khas ayam panggang. Pemanggangan filtrat kaldu dengan substitusi tepung hati ayam menyebabkan aroma kaldu ayam instan berubah menjadi lebih gurih dengan aroma khas ayam panggang. Pada FO yang merupakan formula tanpa substitusi tepung hati ayam aroma khas ayam panggang tidak terdeteksi. Perbedaan aroma pada formula dengan dan tanpa substitusi tersebut terjadi karena saat pemanggangan tepung hati ayam, senyawa heterosiklik volatil bereaksi dengan komponen sulfur dengan berikatan pada cincin ke-3, sehingga reaksi tersebut diduga berperan dalam memunculkan aroma khas ayam panggang pada produk ${ }^{11}$.
Perbandingan mean rank pada mutu organoleptik aroma bahwa rata-rata panelis memiliki preferensi pada aroma kaldu yang gurih dan khas ayam panggang dibandingkan hanya gurih saja. Namun aroma khas ayam panggang yang intensitasnya lebih kuat justru kurang disukai, karena pada formula dengan substitusi $40 \%$ tepung hati ayam disertai peningkatan aroma amis khas hati ayam yang kurang disukai oleh panelis. Selain karena aroma amis khas hati ayam, penurunan kesukaan panelis terhadap F3 diduga disertai pula dengan pengaruh dari reaksi maillard yang juga dapat membentuk aroma yang tidak dikehendaki $^{12}$. Pemanasan hati ayam menyebabkan denaturasi protein sehingga senyawa inorganik seperti zat besi terlepas dan mengambil elektron dari senyawa lain seperti asam lemak, yang jika teroksidasi menimbulkan aroma anyir dan menyengat ${ }^{13}$. Namun analisis statistik dengan Kruskall Wallis menunjukkan substitusi tepung hati ayam ke dalam kaldu ayam instan tidak memberikan pengaruh secara nyata ( $p$-value $=0,629)$ pada indikator aroma.

\section{Nilai Organoleptik Tekstur}

Tekstur merupakan indikator mutu organoleptik yang dinilai dengan kombinasi dari indera pengelihatan (visual texture), peraba (tactile texture), dan pendengaran (auditory texture) $)^{8}$. Mean rank pada mutu organoleptik tekstur dapat dilihat pada Tabel 3. Pada tabel terlihat F3 yang memiliki tekstur bubuk halus dengan tingkat kelembapan tertinggi mendapatkan hasil skor mean rank paling tinggi dengan nilai 3,40. Perbandingan dengan formula FO menunjukkan bahwa modifikasi substitusi tepung hati ayam ke dalam produk kaldu ayam instan memberikan tekstur yang lebih lembab pada produk. 
Dari keempat formula dapat disimpulkan panelis memiliki preferensi kesukaan tekstur kaldu dengan bubuk halus dan lebih lembab. Perbedaan tekstur pada formula diduga karena perbandingan substitusi tepung hati ayam yang lebih tinggi. Hati ayam mengandung protein yang memiliki daya ikat air atau disebut Water Holding Capacity (WHC). WHC merupakan kemampuan daging untuk mempertahankan air saat diberikan suatu tekanan atau pengolahan seperti pemotongan, penggilingan dan pemanasan ${ }^{13}$, sehingga semakin banyak kandungan hati ayam menyebabkan kadar air pada produk menjadi lebih tinggi dan tekstur menjadi lebih lembab. Penelitian pemanfaatan hati ayam pada pengembangan bubur bayi juga menunjukkan hasil yang serupa yakni kadar air yang lebih tinggi ditemukan pada formula dengan perlakuan penambahan hati ayam ${ }^{7}$. Hasil analisis statistik menggunakan Kruskall Wallis menunjukkan substitusi tepung hati ayam memberikan pengaruh secara nyata ( $p$-value $=0,000)$ pada indikator tekstur. Selanjutnya hasil uji Mann Whitney menunjukkan bahwa perbedaan secara signifikan terlihat antara FO dengan semua formula lainnya (FO-F1, FO-F2, dan FO$\mathrm{F3})$, sementara analisisis dengan perbandingan antar formula modifikasi tidak memperlihatkan perbedaan tekstur secara signifikan. Dari hasil kedua uji tersebut dapat disimpulkan bahwa substitusi tepung hati ayam mempengaruhi perubahan tekstur kaldu yang lebih disukai oleh panelis.

\section{Nilai Organoleptik Rasa}

Mutu organoleptik rasa dapat dinilai menggunakan bantuan indera perasa lidah untuk mempersepsikan interaksi dari kombinasi 4 (empat) rasa dasar: manis, asin, asam, dan pahit ${ }^{8}$. Hasil penilaian rasa dapat dilihat pada Tabel 4. Mean rank tertinggi pada rasa diperoleh pada F1 dengan nilai 3,03 dan karakteristik rasa yang gurih dan asin. Skor terendah diperoleh pada F0 dengan nilai 2,17 dengan karakteristik rasa gurih saja. Rasa yang lebih asin pada produk ditemukan seiring bertambahnya substitusi tepung hati ayam.

Panelis memiliki preferensi rasa yang sedikit asin namun tidak terlalu asin.
Perbedaan rasa pada formula diduga karena substitusi tepung hati ayam yang telah diolah dengan bumbu yaitu bawang bombay dan bawang putih sehingga meningkatkan rasa asin pada produk ${ }^{14}$. Hasil analisis Kruskall Wallis pada rasa menunjukkan substitusi tepung hati ayam memberikan pengaruh secara signifikan ( $p$-value $=0,007)$. Kemudian uji lanjutan Mann Whitney juga menunjukkan perbedaan secara signifikan antara FO dengan F1. Namun analisis perbandingan antar formula lainnya tidak menunjukkan hasil yang signifikan. Sehingga dapat disimpulakan substitusi tepung hati ayam sebanyak $10 \%$ memberikan pengaruh rasa yang paling disukai oleh panelis.

\section{Penilaian Keseluruhan Mutu Organoleptik}

Hasil penilaian mutu organoleptik diakumulasi untuk mengetahui formula dengan skor tertinggi. Formula dengan akumulasi skor tertinggi selanjutnya ditetapkan sebagai formula terbaik yang paling disukai oleh panelis. Hasil perbandingan akumulasi skor mutu organoleptik pada tiap formula disajikan pada Gambar 1.

Pada gambar menunjukkan bahwa F1 memiliki skor akumulasi tertinggi dibandingkan dengan formulasi lainnya. F1 yang mengandung substitusi tepung hati ayam sebanyak $10 \%$ lebih disukai panelis terutama pada mutu organoleptik aroma dan rasa. Sehingga F1 ditetapkan menjadi formula terbaik yang dilakukan analisis kandungan zat besi, protein, lemak, dan kadar air di laboratorium.

\section{Analisis Kandungan Gizi Kaldu Ayam Instan}

Kandungan gizi pada formula kaldu ayam instan terbaik (F1) dianalisis kadar protein, lemak, air, dan zat besi. Hasil analisis zat gizi pada $100 \mathrm{~g}$ produk disajikan pada Tabel 5. Protein adalah salah satu makronutrien yang berperan menjalankan fungsi imunitas, regenerasi jaringan yang rusak dan pertumbuhan ${ }^{15}$. Kadar protein dari formula kaldu ayam instan terpilih sebanyak $10,24 \%$, hal tersebut sudah memenuhi standar mutu kaldu (min. 7\%) menurut SNI 1996 dalam penelitian Octaviyanti tentang pembuatan kaldu ayam bubuk $^{16}$. Kandungan 
protein tersebut lebih tinggi dibandingkan dengan kandungan protein dalam produk komersial serupa, karena hati ayam mengandung protein yang tinggi yaitu $16,92 / 100 \mathrm{~g}^{17}$. Dalam menjalankan fungsinya, protein dapat membantu penyerapan zat besi, terutama sumber hewani, sehingga konsumsi dengan jumlah yang cukup dapat mencegah 3,48 kali resiko terkena anemia jika dibandingkan dengan orang yang kurang mendapatkan asupan protein ${ }^{18}$.

Tabel 5. Hasil Analisis Kandungan Gizi Formula Terbaik (F1) Produk Kaldu Ayam Instan (per $100 \mathrm{~g}$ )

\begin{tabular}{lcc}
\hline Kandungan Gizi & Kadar & Standar $^{19}$ \\
\hline Protein (\%) & 10,24 & Min. 7 \\
Lemak (\%) & 2,87 & - \\
Air (\%) & 3,67 & Max. 4 \\
Zat Besi (ppm) & 20,42 & - \\
\hline
\end{tabular}

Rasa dan aroma khas daging pada olahan pangan berbahan dasar unggas dipengaruhi oleh keberadaan lemak ${ }^{11}$. Kadar lemak dalam $100 \mathrm{~g}$ kaldu ayam instan formula F1 sebanyak 2,87\%. Kandungan lemak tersebut lebih tinggi dibandingkan produk komersial serupa karena hati ayam mengandung kandungan lemak yang lebih tinggi yaitu $4,83 \mathrm{~g} / 100 \mathrm{~g}^{17}$. Lemak berfungsi sebagai sumber energi dan juga berperan dalam memperbaiki tekstur dan cita rasa, dalam hal ini lemak meningkatkan rasa gurih pada kaldu ayam instan ${ }^{19}$. Kandungan lemak atau lipida terdegradasi saat pengolahan dengan suhu panas dan menghasilkan komponen karbonil yang merupakan pembentuk rasa gurih khas daging ayam ${ }^{12}$.

Air dalam kandungan kaldu bubuk mempengaruhi penampilan, tekstur, cita rasa dan daya simpan ${ }^{20}$. F1 mengandung kadar air sebanyak 3,67\%, dan kadar tersebut masih sesuai dengan standar air pada kaldu bubuk (max. 4\%) seperti pada penelitian pengembangan kaldu ayam bubuk dengan penambahan sari bayam hijau ${ }^{16}$. Produk dalam bentuk bubuk perlu memperhatikan kadar air karena berpengaruh pada pertumbuhan mikroorganisme, sehingga jika kadar air yang lebih rendah dapat meminimalisasi resiko kerusakan pada produk dan membuat masa simpan menjadi lebih lama ${ }^{21}$.

Zat besi adalah mikronutrien yang berperan penting dalam mencegah terjadinya anemia gizi zat besi terutama pada wanita ${ }^{15}$. Kadar zat besi pada produk F1 sebesar 20,42 ppm atau 2,04 $\mathrm{mg}$, sehingga penambahan hati ayam menambah kandungan zat besi yang tidak terkandung pada produk kaldu ayam instan komersial. Dalam pencegahan anemia konsumsi zat besi merupakan salah satu yang esensial, karena defisiensi konsumsi zat besi meningkatkan resiko terkena anemia hingga 276 kali lebih besar ${ }^{18}$. Kandungan zat besi lebih rendah dari ekspektasi jika dibandingkan dengan zat besi yang terkandung pada hati ayam mentah, karena hal tersebut merupakan pengaruh dari pemanasan berulang selama pembuatan produk. Sehingga penambahan NaFeEDTA dapat membantu mencegah penurunan kandungan zat besi dan juga terhambatnya absorbsi zat besi ${ }^{7}$.

\section{KESIMPULAN}

Berdasarkan hasil uji mutu organoleptik diperoleh formula F1 (substitusi tepung hati ayam $10 \%$ ) sebagai formula dengan akumulasi mean rank tertinggi. Formula F1 kemudian dianalisis kandungan gizinya, dan hasil analisis laboratorium menunjukkan produk (100 g) mengandung 10,24 g protein, 2,87 g lemak, 2,04 mg zat besi, dan 3,67\% air. Kandungan protein dan air sudah sesuai standar kaldu bubuk. Produk modifikasi kaldu ayam instan dengan substitusi tepung hati ayam unggul pada kandungan protein dan zat besi yang lebih tinggi dibandingkan produk komersial serupa, sehingga baik digunakan sebagai alternatif bumbu tambahan untuk mencegah anemia.

\section{ACKNOWLEDGEMENT}

Penulis menghaturkan terima kasih kepada: Mahasiswi UNAIR yang bersedia untuk turut serta menjadi panelis, Industri UKM Toga Citra yang telah berbaik hati membagi resep kaldu bubuknya, dan pembimbing yang telah memberi banyak saran selama penelitian berlangsung. 


\section{REFERENSI}

1. Badan Penelitian dan Pengembangan Kesehatan. Riset Kesehatan Dasar (RISKESDAS) 2013. Lap. Nas. 2013 1-384 (2013). doi:1 Desember 2013

2. Depkes. Permenkes No. 75 tahun 2013 tentang AKG 2013. 10 (2013).

3. Degerud, E. M., Manger, M. S., Strand, T. A. \& Dierkes, J. Bioavailability of iron, vitamin A, zinc, and folic acid when added to condiments and seasonings. Ann. N. Y. Acad. Sci. 1357, 29-42 (2015).

4. Mosby, I. 'That Won-Ton Soup Headache': The Chinese Restaurant Syndrome, MSG and the Making of American Food, 1968-1980. Soc. Hist. Med. 22, 133-151 (2009).

5. Simbolon, D.O.S., Masfria., S. Pemeriksaan Kadar Fe dalam Hati Ayam Ras dan Ayam Buras secara Spektrofotometri Serapan Atom. J. Nat. Prod. Pharm. Chem. 1, 8-13 (2012).

6. Hutchison, M., Harrison, D., Richardson, I. \& Tchórzewska, M. A method for the preparation of chicken liver pâté that reliably destroys campylobacters. Int. J. Environ. Res. Public Health 12, 4652-4669 (2015).

7. Santosa, H., Handayani, N. A., Nuramelia, C. \& Sukma, N. Y. T. Pemanfaatan Hati Ayam sebagai Fortifikan Zat Besi Dalam Bubur Bayi Instan Berbahan dasar Ubi Jalar Ungu (Ipomoea batatas L.). Inov. Tek. Kim. 1, 27-34 (2016).

8. Lawless, H. T. \& Heymann, H. Sensory Evaluation of Food. (2010). doi:10.1007/978-1-4419-6488-5

9. Nisya, I.P.A., Ayustaningwarno, F. Pengaruh Substitusi Tepung Daging Ikan Lele Dumbo (Clarias Gariepinus) dan Tepung Ubi Jalar Kuning (Ipomea Batatas L.) Terhadap Kandungan Zat Gizi dan Penerimaan Biskuit Balita TInggi Protein dan $\beta$ - Karoten. J. Nutr. Coll. 2, 89-97 (2013).

10. Shankar, M. U., Levitan, C. A., Prescott, J. $\&$ Spence, $C$. The Influence of Color and Label Information on Flavor Perception. Chemosens. Percept. 2, 53-58 (2009).

11. Wettasinghe, M., Vasanthan, T., Temelli,
F. \& Swallow, K. Volatiles from roasted byproducts of the poultry-processing industry. J. Agric. Food Chem. 48, 34853492 (2000).

12. Purba, M. Pembentukan Flavor Daging Unggas oleh Proses Pemanasan dan Oksidasi Lipida. Wartazoa 24, 109-118 (2014).

13. Kerth, C. R. The Science of Meat Quality. The Science of Meat Quality (2013). doi:10.1002/9781118530726

14. Batenburg, M. \& van der Velden, R. Saltiness Enhancement by Savory Aroma Compounds. J. Food Sci. 76, S280-S288 (2011).

15. Adriani, M., Wirjatmadi, B. Peranan Gizi dalam Siklus Kehidupan. (Penerbit Kencana, 2014).

16. Nadhia, O., Bambang, D., B. E. Mutu Kimiawi Dan Mutu Organoleptik Kaldu Ayam Bubuk Dengan Penambahan Sari Bayam Hijau. J. Apl. Teknol. Pangan 6, 94-97 (2017).

17. USDA Agriculture Research Service. USDA National Nutrition Database for Standart Reference 28: Chicken liver, all classes, raw. (2016).

18. Syatriani, S. \& Aryani, A. Konsumsi Makanan dan Kejadian Anemia pada Siswi Salah Satu SMP di Kota Makassar. J. Kesehat. Masy. Nas. 4, 251-254 (2010).

19. Meiyani, D.N.A.T., Riyadi, P.H., Anggo, A. Pemanfaatan Air Rebusan Kepala Udang Putih ( Penaeus merguiensis) Sebagai Flavor Dalam Bentuk Bubuk Dengan Penambahan Maltodekstrin. J. Pengolah. dan Bioteknol. Has. Perikan. 3, 67-74 (2014).

20. Swasono, M. A. Optimasi Pengolahan Kaldu Ayam dan Brokoli dalam Bentuk Instan dan Analisa Biaya Produksi. (Universitas Brawijaya, 2008).

21. Herawati, H. Penentuan umur simpan pada produk pangan. J. Litbang Pertan. 27, 124-130 (2008). 